\title{
O Estado Laico e a Liberdade Religiosa como proposta eleitoral: Fernando do Ó e as eleições de 1933. ${ }^{*}$
}

\author{
The Secular State and Religious Freedom as election proposal: \\ Fernando $O$ and Elections of 1933.
}

\author{
Beatriz Teixeira Weber ${ }^{* *}$ \\ Renan Santos Mattos ${ }^{* * *}$
}

RESUMO

Este texto persegue a posição política de Fernando Do Ó, militar, advogado e importante liderança espírita da cidade de Santa Maria nas décadas de 1930 a 1950, por ocasião de sua candidatura como Deputado Federal pela Liga Pró-Estado Leigo para a Assembleia Nacional Constituinte de 1934. Tendo por base a noção de campo religioso de Pierre Bourdieu, e a partir de artigos do Diário do Interior, busca-se analisar o papel social da religião e suas relações com a política, em que a defesa da laicidade e da liberdade religiosa constituía-se como ponto de congregação de diferentes vertentes religiosas.

Palavras-chave: Liberdade Religiosa. Laicidade. Eleições de 1933.

ABSTRACT

This text pursue the political position of Fernando do Ò, military, lawyer and spiritualist who worked in Santa Maria from 1930 to 1950 on the occasion candidate of the League Pró-Estado Leigo in Rio Grande do Sul during the Constituent Assembly of 1934. Based on the religious notion of religious field of Pierre Bourdieu, and from articles Daily Interior seeks to analyze the social role of religion and its relations with politics, In which the defense of secularity and religious freedom constituted as a point of congregation of different religious aspects.

Keyword: Religious freedom. Laicity. Elections of 1933.

\footnotetext{
* - Este texto vincula-se a pesquisa de tese sobre Fernando do Ó, importante liderança espírita da Cidade de Santa Maria

${ }^{\text {** }}$ Universidade Federal de Santa Maria

${ }^{* * *}$ Universidade Federal de Santa Maria. E-mail: renansnatos@gmail.com
} 


\section{Introdução}

A Constituinte de 1934 é um elemento instigante da história republicana brasileira. O cenário imediato pós-30, a partir do que, historiograficamente, ficou conhecido como vazio de poder, permitiu a efervescência social e as disputas entre as diversificadas forças sociais ${ }^{1}$. Assim, o valor de tal experiência constitucional, conforme Ângela de Castro Gomes (1990, p. 56), decorre do processo que a gerou, pleno de revisões e reflexões políticas. Seus pressupostos entre o moderno e o conservador endossam a perspectiva eclética e conciliadora da Carta Magna (CEPEDA, 2009, p. 2).

Diante dessa problemática, o presente artigo analisa o contexto de eleições para Assembleia Nacional Constituinte de 1934, tendo por referência a candidatura de Fernando do Ó para Deputado Federal pelo Partido Pró-Estado Leigo e sua defesa a favor do Estado Leigo $^{2}$. Nessa lógica, tendo por objeto a trajetória política de Fernando Souza do Ó, almejamos demarcar os arranjos da presença do religioso no político, e em que medida problemas do contexto histórico foram debatidos à luz de tal realidade histórica ${ }^{3}$.

Este trabalho se insere na pesquisa do que definimos de projeto de espiritismo kardecista colocado em prática por um conjunto de membros que se definiram enquanto "propagandistas" do espiritismo na cidade de Santa Maria entre 1930 e 1940, inseridos no âmbito da cultura letrada e do pensamento liberal em construção desde o fim do século XIX na cidade. Assim, justificamos Fernando do Ó enquanto agente expoente desse grupo de propagandistas, pois sua trajetória permite evidenciar os arranjos e configurações do mundo social em que se inseriu, ressignificando elementos, como o laicismo e a liberdade religiosa, frente ao tradicional catolicismo ultramontano ${ }^{4}$.

\footnotetext{
${ }^{1}$ Luciano Aronne de Abreu (2007, p. 173), partindo de Boris Fausto, aponta que "a Revolução de 3 de outubro não foi a expressão de uma oposição radical entre os interesses agrários e industriais, pois havia uma complementaridade entre esses setores". Logo, define esse regime nos seguintes termos: "pode-se afirmar que a formação de um Estado de Compromisso não ocorreu durante o chamado Governo Provisório, mas se estendeu por toda a Era Vargas, sendo uma de suas principais marcas." (ABREU, 2007, p. 173-174). É possível relacionar, desse modo, o apoio de diferentes segmentos da sociedade, tais como o Exército, as oligarquias estaduais, as classes produtoras, a Igreja e os integralistas.

${ }^{2}$ Fernando do Ó alcança 1696 votos, não conquistando vaga para a Constituinte (Diário do Interior, 4 maio 1933).

${ }^{3}$ Ângela de Castro Gomes ressalta que "a categoria cultura política foi defi nida como 'um sistema de representações, complexo e heterogêneo', mas capaz de permitir a compreensão dos sentidos que um determinado grupo (cujo tamanho pode variar) atribui a uma dada realidade social, em determinado momento do tempo." (GOMES, 2005b, p. 31).

${ }^{4} \mathrm{O}$ termo ultramontano foi usado pelos franceses para indicar que, na visão deles, o papa vive após as montanhas. Mas é no seu ideário que o termo ganha força. Diz respeito à política de Pio IX e sua busca em centralizar as decisões na figura do Sumo Pontífice, submeter a Igreja à hierarquia tendo o papa como infalível (AZEVEDO, 1999, p. 445-446).
} 
O corpus documental deste trabalho prioriza a atividade pública de Fernando do Ó. Utilizamos como fonte principal os artigos produzidos pelo autor junto ao Diário do Interior, complementados pela documentação da instituição espírita Aliança Espírita SantaMariense no recorte de $1930-1940^{5}$. A partir do recorte de textos presentes no Diário do Interior, tanto dimensionamos as questões da concorrência do campo religioso de Santa Maria-RS, quanto evidenciamos um conjunto de vozes em tensão em relação à pretendida conformação da identidade católica na cidade e no Brasil no pós-30.

O Diário do Interior foi fundando em 1911, sendo a primeira folha de propriedade do anglicano Alfredo Rodrigues da Costa. O periódico de cunho independente e sem explícita vinculação partidária ${ }^{6}$ buscava reforçar a modernidade que chegara com o trem na cidade. Voltado para temas como política, sociedade e o cenário internacional, a Seção Telégrafo, por exemplo, veiculava notícias do estado e do país, ao mesmo tempo em que veiculava notícias de outros jornais, como Diário Carioca e Diário da Noite. O periódico trazia, em suas páginas, todos os aspectos da vida cotidiano da cidade: a movimentação teatral, os lançamentos no cinema, as feiras literárias, as ofertas de hotéis e do comércio, sendo o mais popular da cidade de Santa Maria até a sua extinção em 1939.

Frente ao delineamento do jornal enquanto espaço de sociabilidade e lugar de disputas simbólicas das diferentes denominações religiosas, bem como teatro de investidas e consolidação do poder simbólico ${ }^{7}$, mostra-se oportuno referenciar que:

[...] jornais e revistas não são, no mais das vezes, obras solitárias, mas empreendimentos que reúnem um conjunto de indivíduos, o que os torna projetos coletivos, por agregarem pessoas em torno de ideias, crenças e valores que se pretende difundir a partir da palavra escrita. (LUCA, 2005, p. 140).

Nesse sentido, a presente pesquisa aventura-se sobre a problemática da ampliação da pesquisa histórica, tendo o jornal e a imprensa como fonte. A historiadora Tânia Regina de Luca (2005) ressalta a importância da revisão conceitual e paradigmática em torno dos interesses do historiador nas mais variadas correntes historiográficas. O cotidiano, o corpo,

\footnotetext{
${ }^{5}$ Optou-se, nesta pesquisa, pela modificação à escrita original de forma a facilitar a leitura.

${ }^{6}$ Conforme Renée Barata Zicman (1985, p. 91-92), os periódicos da década de 1940/50 caracterizam-se por sua escrita de opinião, assim, primavam por suas posições particulares, o que se costuma chamar de imprensa de opinião, carregada de elementos políticos e apaixonados, dirigindo-se a um público-alvo, sendo o jornalismo quase um exercício literário. ${ }^{7}$ Bourdieu (1996) ressalta uma potencialidade de análise das práticas e representações religiosas, inserindo tais disputas simbólicas pelo poder, e o campo religioso definindo como lugar de tensões e espaço de luta . Logo, infere-se o poder simbólico enquanto o desejo de nomear a realidade e impor certa visão de mundo, amplamente reconhecida. Em consequência disso, as disputas simbólicas estariam atreladas a essas disposições de poder e o posicionamento em que os agentes e instituições no referido campo. Sobre o assunto ver: Bourdieu (1996).
} 
a práticas sociais do imediato e a renovação do político repercutiram no olhar do historiador brasileiro e estabeleceram novos significados para a imprensa como porta-voz das inquietudes, anseios de diferentes grupos, historicidades e projetos sociais.

Renée Barata Zicman (1985) resume em três elementos significativos e particulares da fonte jornalística, como a periodicidade, o potencial para referenciar o cotidiano e as memórias sociais constituídas. Logo, ressalta o transitar da informação e a construção em torno do saberes no contexto histórico, bem como o tipo de censura, o que, para o autor, exige o olhar da imprensa a partir de suas particularidades e a necessidade de historicização do jornal.

Tal prática metodológica deve levar em conta a ideia de escrita de imprensa, levando em consideração que a imprensa lida como sentidos e representações do real próprios, decorrentes tanto da sistematização da imprensa global quanto do modo de operar a informação jornalística. Por isso, considerar seus diferentes elementos envolve a construção do fato jornalístico, que subentende todo o processo de escrita em si: sua materialidade e composição. Nas palavras de Luca (2005, p.140):

[...] os discursos adquirem significados de muitas formas, inclusive pelos procedimentos tipográficos e de ilustração que os cercam. A ênfase em certos temas, a linguagem e a natureza do conteúdo tampouco se dissociam do público que o jornal ou revista pretende atingir.

Por isso, para a compreensão acerca da questão de público-alvo e leitor, buscou-se a leitura proposta por Cláudio Pereira Elmir (1995). Assim, o autor evidencia a complexidade entre a informação histórica e a construção de tal discurso e seu uso na pesquisa histórica. Desse modo, adverte para a importância de uma leitura meticulosa, demorada, exaustiva do jornal. E assim propõe:

[...] devemos fazer uma "leitura intensiva" destes jornais e não uma "leitura extensiva". Ler os jornais extensivamente é o que fazemos diariamente hoje. Ler intensivamente é o que acontece com leitores cujo tempo da experiência da leitura não corresponde ao tempo da formulação do jornal. (ELMIR, 1995, p. 21) 
Tal assertiva refere-se ao fato de que o tempo da experiência da nossa leitura é diferente do tempo de formulação do discurso do jornal:

[...] a questão metodológica fundamental é ter presente que nós pesquisadores não somos os leitores-modelo do jornal. Nós somos leitores empíricos de um jornal que teve outros leitores empíricos no momento em que circulava. (ELMIR, 1995, p. 22)

Salienta-se que, através da pesquisa em jornais, almejamos analisar o contexto histórico, o cotidiano e as disputas presentes no contexto de Santa Maria. Aliás, como escreve Marta Borin (2010, p. 34): "través da imprensa, apontaremos ainda para uma atmosfera de tensão e conflito na cidade de Santa Maria. Estes impressos são reveladores de uma contenda entre o poder coercitivo dos agentes sociais através dos diferentes campos em que atuavam".

Ao problematizarmos a historicidade e o significado que os indivíduos e as coletividades concebem acerca do real, mostra-se oportuno lançarmos algumas questões que circundam o discurso do jornal. Assim, não desconsideramos que "o documento é produzido consciente ou inconscientemente pelas sociedades do passado, tanto para impor uma imagem desse passado quanto para dizer 'a verdade" (LE GOFF, 1990, p . 54-55). Portanto, tais fontes exprimem uma visão de mundo condicionada por experiências e interesses específicos de quem as produziu.

Diversas colunas compunham os espaços do jornal: "Pelo Espiritismo" estava vinculada ao movimento espírita na cidade, já a "Seção Religiosa" representava o espaço reservado à Igreja Católica, às ações dos leigos e às festas populares, além disso, notícias sobre reuniões anglicanas e a maçonaria também tinham seu espaço. $O$ jornal trazia toda a pluralidade cultural da cidade de Santa Maria e, por esse motivo, era pouco recomendado pela Igreja Católica (BORIN, 2010). Ressaltamos, ainda, a presença de figuras ilustres do cenário da cidade, como João Belém, Diógenes Cony, Padre José Busa to, Padre Huberto Rohden, Adely de Albuquerque, entre outros, que, com suas posições políticas, interferiam no espaço da cidade e do Brasil. Assim, delineamos esse espaço como o lugar social de atuação de Fernando do Ó como articulista do referido jornal. 


\section{Fernando do Ó: o intelectual e espírita da cidade de Santa Maria}

Fernando Souza do Ó tem uma trajetória excepcional no interior das disputas religiosas tecidas na década de 1930. Nasceu em 30 de maio de 1895, na cidade de Campina Grande, no estado da Paraíba, filho de Manoel Souza do Ó e de Maria da Conceição Rocha ${ }^{8}$. É um dos 24 filhos do casal. Quando Fernando do Ó tinha 15 anos de idade, ingressou como voluntário na Companhia de Caçadores no estado do Mato Grosso, e aportou em Santa Maria na gradua ção de $3^{\circ}$ Sargento em 1913, sendo designado para o $7^{\circ}$ Regimento de Infantaria.

A situação solitária, numa cidade distante, delineava o cotidiano de Fernando do Ó. Assim, um ponto destacado, pela biografia escrita por Fernando Corrêa, ressaltava que Fernando do Ó realizava, todos os dias, suas refeições na pensão da Dona Honorina Nunes Pereira. Nesse ambiente, conheceu Maria Altina, uma das filhas da Dona Honorina, que servia as mesas no estabelecimento. Em 1913, Maria Altina e Fernando do Ó oficializa ram o compromisso mediante o noivado, casando-se em 31 de julho de 1915. Começava, assim, a família do Ó, constituída de uma prole de dez filhos.

Em 1915, ainda atuando como sargento, passou a fazer parte da Loja Maçônica Luz e Trabalho. Tal loja nasceu da fusão, em 1907, das lojas Luz e Fraternidade, e Paz e Trabalho. Segundo Véscio (2010), as lojas e o Grande Oriente (GORGS) eram movidos pelo pensamento anticlerical e decorrente das discussões realizadas nessas lojas ${ }^{9}$. Nesse sentido, inferimos suas conexões com o pensamento anticlerical e laico defendido por Fernando do Ó.

Fernando do Ó empreendeu um estudo sistematizado da doutrina elaborada por Allan Kardec, atuando incisivamente na cidade de Santa Maria. Denominando-se como "propagandista", participou, juntamente com Otacílio Aguiar, da fundação de diversas instituições espíritas: Sociedade Espírita União, Luz e Caridade (1929), Sociedade Espírita Discípulos de Jesus (1940), Sociedade Espírita Oscar José Pithan (1949), bem como em processos em cruzadas de divulgação do espiritismo a partir de doutrinárias. E essa memória é reforçada por Edmundo Cardoso (1978, p. 233), importante memorialista da cidade:

\footnotetext{
${ }^{8}$ Nossa principal fonte de informação sobre é a biografia escrita por Fernando Corrêa (2004), neto do autor.

${ }^{9}$ Temos uma vasta bibliografia acerca das disputas religiosas vivenciad as na cidade de Santa Maria, entre os trabalhos destacamos: Biasoli (2010), Kasburg (2007)e Borin(2010), que, em nossa leitura, indicam o jogo de tensões, interesses e uma pluralidade de agentes falando sobre si, sobre seu mundo e defendendo suas concepções.
} 
O Espiritismo lhe deve, sobretudo, uma faceta de rara importância e robustez indizível: doutrinador vigoroso, firme e inabalável, dono de convicções admiráveis e contagiantes, numa perenidade de propósitos que lhe dava uma posição ímpar e brilhante na doutrina de Kardec. Respeitado, consultado, atuava como árbitro fiel, justo e apontador dos rumos. Legítima e incontrastável figura apostolar, para melhor identificação do homem dentro de sua religião.

Por fim, a trajetória de Fernando do Ó oferece elementos para referenciar a noção de constituição de campo intelectual, fato frequentemente referendado em sua trajetória. Nesse sentido, algumas constatações reafirmam uma identidade em construção: "Fernando do Ó não se contentava em trabalhar apenas para sustentar a numerosa família, tinha ânsia de sabedoria e cultura, por isso estudava com afinco e perseverança. Era autodidata." (CORREA, 2004, p. 35).

O ano de 1932 é delimitador em sua projeção no espaço da cidade. Após a conclusão do curso de Direito na Faculdade de Pelotas, surgia, então, o Doutor Fernando do Ó. A importância da presença de Fernando do Ó na sociedade santa-mariense pode ser constatada a partir das homenagens registradas nas páginas do jornal Diário do Interior, em 14 de dezembro de 1932. Iniciava-se, assim, segundo Corrêa (2004), uma trajetória de sucesso na "ciência do Direito". Após seu licenciamento e transferência para a reserva, em 1934, no posto de $1^{\circ}$ Tenente, atuou principalmente nas áreas civil e criminalista. Em 1940, participou da fundação da Sociedade Rio-Grandense de Criminologia, sendo presidente da 6 a Subseção da Ordem dos Advogados nos anos de 1940.

Além de advogado, atuou como jornalista, fazendo parte de diversos jornais do Rio Grande do Sul e de outros estados, além da atuação permanente na imprensa espírita. Sua produção literária é vasta, com sete romances espíritas no período de 1930 a 1960: "Marta" (1933), "Almas que voltam" (1938), "E as vozes falaram" (1946), "Apenas uma sombra de mulher" (1950), "Alguém chorou por mim" (1955), "A dor do meu destino" (1956) e "Uma luz no meu caminho" (1961). Peças teatrais ${ }^{10}$ e críticas literárias faziam parte de seu dia a dia, assim, decifrá-lo mostra-se como uma possibilidade de evidenciar sua historicidade. Tratamos, aqui, de um projeto apresentado por Fernando do Ó e o bojo de conexões resultantes desse processo. Sua inserção política revelou-se uma alternativa das possibilidades evidenciadas em um momento de sua vida, fruto de diferentes estratégias

\footnotetext{
${ }^{10}$ Na década de 1930, destacou-se com Lamartine Souza e Rubem Belém na constituição de campo teatral e cultural em Santa Maria. Em 1938, escreveu A aposta. Participou da fundação da Escola de Teatro Leopoldo Fróes, em 1943, juntamente com Edmundo Cardoso e atuou como crítico de peças teatrais no Jornal Diário do Interior e A Razão. Ver Corrêa (2004).
} 
num tempo de expectativas de liberdade religiosa, com a construção e a uso do conceito de Laicismo, ou seja, proposições para a sociedade brasileira.

\section{O Laicismo como sociabilidade política}

Os anos de 1930 trazem indícios de conexões inéditas entre religião e política no Brasil. A emergência de grupos e de instituições gerenciadas pelo laicato católico, com o objetivo de auxiliar na ação político-religiosa da Igreja rumo à sua "restauração" no seio da sociedade brasileira, viabilizou novos atores e espaços sociais. Assim, foi criado, no Rio de Janeiro, o Centro Dom Vital, a revista "A Ordem" e, na década de trinta, a Liga Eleitoral Católica e a Confederação Católica Brasileira de Educação (CCBE). Essas instituições tinham o objetivo de combater os anticlericais e de divulgar aos brasileiros as ideias advindas do clero.

Reforçando a complexidade desse contexto, Sérgio Miceli (2001) enfatiza as ações da Igreja Católica no intuito de ampliar sua influência na sociedade. Segundo o autor, "a amplitude desse projeto resultava não apenas das diretrizes do Vaticano, então preocupado em sustar o florescimento dos movimentos operários de esquerda na Europa, mas também da tomada de consciência por parte do episcopado brasileiro da crise com que se defrontavam os grupos dirigentes oligárquicos" (MICELI, 2001, p. 130).

Nessas palavras, havia uma tensão nos anos que sucederam a década de 1920 e tiveram seu apogeu durante o pós-30. As relações entre Estado e religião evidenciavam tentativas de negociação e debates levados a cabo por diferentes agentes e revelavam a ebulição da busca por certas definições. Possibilitam, também, refletir como os agentes entendiam certos conceitos, como cidadania, laicismo, religião e Estado. Sumariamente, o que vamos discutir é a tomada de posições de Fernando do Ó no conjunto de disputas religiosas em nível local, que converge, como assinala Aline Coutrot, para "as possibilidades desencadeadas mediante as considerações do religioso, a apreensão dos comportamentos coletivos e, sobretudo, de elementos que constituem a cultura política" (COUTROT, 1996, p. 357).

Em meio à percepção dessas ambições políticas por parte do clero, principalmente, com as discussões sobre o decreto que previa a obrigatoriedade do ensino religioso nas escolas públicas e privadas ${ }^{11}$, um conjunto de reações de grupos opositores ao catolicismo acabou

\footnotetext{
${ }^{11}$ Em 1931, o Ministro da Educação Francisco Campos, por meio do Decreto ${ }^{\circ} 19.941$ de 30 de abril de 1931, instituiu o ensino religioso como disciplina facultativa para compor o currículo das escolas públicas brasileiras,, que instituiu, nas escolas oficiais, nos cursos primário, secundário e normal, o ensino religioso facultativo. Embora não houvesse uma opção clara pelo ensino católico, no entendimento do movimento, essa resolução do governo provisório indicava sua inclinação aos interesses da Igreja Católica, ou, pelo menos, acreditava-se que ela teria força para influenciar o ensino.
} 
por se destacar. Em Santa Maria, por exemplo, organizaram-se reuniões e manifestações visando conter as ambições do clero. Agregando membros da Maçonaria, das igrejas metodistas, luteranas e algumas lideranças espíritas, surgia a Liga Pró-Liberdade.

Em 29 de dezembro de 1930, a Liga Pró-liberdade Religiosa estaria em evidência o cenário da cidade. Fernando do Ó engajou-se no evento organizado pela loja maçônica Luz e Trabalho com o intuito de discutir a liberdade religiosa. Dessa maneira, o jornal "Diário do Interior" trouxe, em matéria do dia 30 de dezembro, notícia que a Luz e Trabalho faria uma reunião em praça pública para abordar o tema da liberdade religiosa em "protesto contra a pretendida oficialização da Igreja Católica Romana"(PRÓ-LIBERDADE..., 1930, p. 3).

A manifestação ocorreu na praça central Saldanha Marinho, em frente à loja Luz e Trabalho. Conforme o jornal, a ocasião reuniu uma multidão, "inclusive católicos que procuraram interromper os oradores" (PRÓ-LIBERDADE..., 1930, p. 3). Participaram do evento lideranças religiosas e intelectuais, como o reverendo anglicano José B. Leão, pároco da Catedral do Mediador, os professores Cícero Barreto e o Tenente Fernando do Ó, ambos da loja Luz e Trabalho, e Diógenes Cony e Octacílio Aguiar, reconhecidos espíritas na cidade. A notícia ainda informa que "elementos jogaram alguns ovos sobre a assistência" (PRÓLIBERDADE..., 1930, p. 3).

O grupo intitulado de Comitê Liberal Pró-Liberdade Religiosa manifestou-se em 15 de janeiro de 1931, com o objetivo de discutir as pretensões do clero e sua relação política com um teor bastante incisivo. Declara: "Imbuídos no amor da nossa terra, a nossa alma desperta sentimentos de repulsa contra essa horda de 200 milhões de clericais espalhados pelo mundo, sob uma formidável organização política, com finalidades mercantis" (COMITE..., 1931, p. 2). Em tom de denúncia, ressalta os caminhos corruptos assumidos pela Igreja Romana, retomando capítulos da história da Igreja, como as Cruzadas, a Inquisição e o batismo como recurso de poder, inserindo tais pontos como malefícios da história humana.

Adiante, o Manifesto passa a discorrer sobre possíveis perturbações psicológicas decorrentes da vida em seminário e do celibato e, a partir de discursos patrióticos e republicanos, conclama uma união anticlerical como um exercício de cidadania, em defesa da liberdade, da união, concluindo em tom apocalíptico: "Avante, concidadãos, cumpramos o nosso dever, caminhemos para a luta, pela vida na liberdade e na morte" (COMITE..., 1931, p. 2).

A liberdade religiosa surge como elemento agregador e de construção identitária para esse grupo. É nesse sentido que outro manifesto da congregação, sob o título de "PróLiberdade da Consciência", justificava os objetivos da agregação, sobretudo o seu combate, e garantia o que estava previsto na Constituição Federal acerca da laicidade. Nessa lógica, o grupo construiu sua identidade nos seguintes termos: "representando centenas de milhares 
de pessoas, que, por nosso intermédio, levantam vibrantíssimo grito de protesto, contra as maquinações da Igreja Católica" (COMITE..., 1931, p. 4).

É importante esclarecer que tais eventos relacionam-se com as manifestações em curso em favor do Estado leigo e da liberdade de consciência recrudescidas nesse cenário. $\mathrm{O}$ movimento fortaleceu-se a partir da criação de comitês e ligas em diversas cidades do estado e do país, sendo criada, no Rio de Janeiro, a Coligação Nacional Pró-Estado Leigo, em 1931, a qual buscava centralizar e referenciar as ações das organizações estaduais. Tal movimento foi liderado, no Rio Grande do Sul, pelos maçons Carlos Frederico de Mesquita e Átila Salvaterra, pelo metodista Frank Long e pelos espíritas Egydio Hervé e Paulo Hecker (MONTEIRO, 2008).

O pós-1932 caracterizou-se por novos arranjos e alianças políticas. Assim, o movimento em torno da liberdade religiosa retomou suas reivindicações a partir das agregações entre as chamadas minorias religiosas.

O bojo de tal mobilização pode ser entendido a partir das propostas autoritárias e reformistas em curso. Ângela de Castro Gomes (2005a) dimensiona o paradoxo de tal pensamento autoritário, já que, frente à falência do liberalismo, tal configuração ideológica atrelou-se à bandeira da democracia, conferindo novos sentidos e apropriações, culminando na construção de um conceito aparentemente paradoxal: “democracia autoritária". Mas qual seria o significado de tal construção? Intelectuais como Oliveira Vianna, Francisco Campos e Azevedo Amaral endossam suas contribuições no sentido de legitimar um modelo ancorado na ação política de Vargas, com seu viés modernizador e corporativista. Nesse sentido, o estado forte e centralizado convergia para "uma nova forma de exercício de poder" (GOMES, 2005a, p. 112), fundamentado na justiça social e na união povo e Estado, cuja abolição "de corpos intermediários entre o povo e o governante" (GOMES, 2005a, p. 112). culminou com o investimento em representações profissionais, de natureza técnica, e desordem econômica, como instrumentos capazes exprimir a vontade geral/popular (GOMES, 2005a, p. 112).

Francisco Campos e suas reformas, dessa maneira, instituíram um projeto de estruturação do ensino secundário, comercial e superior. Segundo Moraes, "pela primeira vez na história da educação brasileira, uma reforma se aplicava a vários níveis de ensino e objetivava alcançar o país como um todo" (MORAES, 1992, p. 293). E, no âmbito de posicionamentos políticos e articulações, o Decreto $\mathrm{n}^{\circ}$ 19.941, de 30 de abril de 1931, que instituiu o ensino religioso como matéria facultativa nas escolas públicas do país, coincidia com as aproximações e o delineamento entre Igreja Católica e o Regime Varguista, em consonância com o projeto de combate ao comunismo e ao liberalismo. Moraes (1992) destaca a perspicácia de Campos e Vargas ao mediar as tensões entre grupos católicos e reformadores no campo educacional. Logo, é possível inferir o investimento em educação voltada para "formar o homem brasileiro", ou seja, como instrumento para imprimir a 
"unidade espiritual" e promover a formação do novo homem brasileiro e da nacionalidade (MORAES, 1992, p. 318).

A Liga Pró-Estado Leigo teve características marcantes no Rio Grande do Sul, embora fosse um movimento nacional (MONTEIRO, 2008). O grupo reivindicou suas causas num congresso realizado nos dias 6, 7 e 8 de janeiro de 1932, no Teatro São Pedro, em Porto Alegre. Lorena Monteiro (2008) ressalta as mudanças ocorridas no segundo e no terceiro Congressos Pró-Estado Leigo. Assim, naquele março de 1933, tratou-se do ensino laico, através dos pronunciamentos da senhorita Lacy Renner (O ensino religioso nas escolas públicas), do professor Armando Lima (Os causadores da infelicidade no Brasil) e do jornalista Agnello Cavalcanti (Os males do ensino sob a direção do romantismo). Portanto, enfatizaram-se questões do ensino.

E diante das pretensões católicas, e "por sugestão do acadêmico Ernesto Barbosa, a Liga lançou chapa própria para as eleições constituintes e apoio a todos aqueles candidatos que se opusessem às pretensões clericalistas" (MONTEIRO, 2008, p. 133). A chapa da Liga constituiu-se por Manuel Serafim Gomes de Freitas, Fernando de Souza do Ó, Eduardo Menna Barreto Jayme, Lucydio Ramos, Alcides Chagas Carvalho, Agnello Cavalcanti de Albuquerque, Ângelo Plastina, Almirante Américo Silvado, Almirante Arthur Thompson e Athalício Pittan.

As preocupações desse grupo caracterizaram inúmeras manifestações de semelhante ordem espalhadas pelo Brasil, fruto de uma mesma inquietação: as ambições do clero católico e o ensino. No Rio de Janeiro, por exemplo, em $1^{\circ}$ de setembro de 1933, realizou-se o $1^{\text {0 }}$ Congresso Leigo Acadêmico, quando discursaram diversos nomes interessados na organização de igrejas livres num estado livre (MONTEIRO, 2008, p. 133).

O contexto da pré-constituinte de 1934, nessa lógica, caracterizou-se pela emergência de novas demandas e suas disputas, logo, assistiu-se a uma série de estratégias. É nessa perspectiva que podemos ler a notícia veiculada em 19 de abril de 1933, na qual percebemos as expectativas e as possibilidades enunciadas por Fernando do Ó e seu grupo de simpatizantes:

Não temos cores políticas; não pertencemos à escola partidária de espécie alguma; não vimos combater governos ou religiões, ou guerrear partidos: vimos tão só, publicamente e veementemente, procurar evitar a mais terrível hecatombe, que certo se desencadeará pelo Brasil, com seu cortejo de fogueiras, guilhotinas e forcas - INQUISIÇÃO! enfim se o clericalismo triunfar sobre as urnas (CONY et al., 1933, p. 3) 
Tal disputa é perceptível na conclusão do artigo, quanto escrevem:

Não queremos consciências escravas de dogmas, preconceitos ou leis absurdas. [...] nós vimos apresentar ao glorioso filho dos pampas, a candidatura de nosso intelectual patrício DOUTOR FERNANDO DO Ó. (CONY et al., 1933, p. 3)

Assim, no sentido de se evitar certos retornos, simbolizados por uma noção histó rica de inquisição, concentraram-se num discurso conciliador e de tolerância, e propuseram a liberdade religiosa e o estado laico, prevista em Constituição, como a forma de paz e de progresso da nação, endossando, assim, sua defesa:

Queremos a liberdade religiosa absoluta tal como garantia o artigo $72 \mathrm{e}$ seus paragraphos da Constituição de 1891. Queremos a Igreja livre no Estado Livre, o ensino laico, obrigatório e gratuito, queremos a paz e o progresso de nosso amado Brasil. (CONY et al., 1933, p. 3)

A notícia do manifesto apresenta a posição pessoal de Fernando do Ó, que defendeu suas proposições e argumentou sobre seu posicionamento político. Assim, o candidato definia sua candidatura "sem cor essencialmente política, de caráter essencialmente popular" Justificando sua inserção como um imperativo de seu tempo, de suas amizades, conclamou sua bandeira nos seguintes termos: "E é só pela tolerância - índice de cultura política e religiosa - que se conhece no adversário os mesmos direitos e deveres" (Ó, 1933b, p. $3)$.

Nesse sentido, Fernando do Ó transitou em eixos que convergiam para questões do campo religioso e de defesa de ordens legais. $O$ primeiro relaciona-se às questões de direitos previstos na Constituição, sobretudo de ordem social, primando pela defesa do Art. 72 da Constituição de 1891, que apontava para as liberdades individuais e para a separação entre a religião e o Estado. Já o segundo e o terceiro aspectos, ainda na ordem da lei, traziam relações entre poder estatal e sociedade.

Por fim, o manifesto de Fernando do Ó menciona as questões religiosas nos seguintes pontos: "Supressão de nossa Embaixada junto ao vaticano". As propostas de Fernando do Ó trataram sobre o ethos católico, sobretudo no que tange à religião e seu ensino. Em nota de 
publicidade do jornal, ratificava-se o quanto Fernando do Ó passou a representar o inimigo público da nação católica:

\author{
Liga Eleitoral Católica \\ Aviso aos Eleitores \\ Previne-se ao eleitorado católico que de nenhuma maneira pode votar \\ no nome do Sr. Fernando do Souza do Ó, candidato à Constituinte, visto \\ o mesmo apresentar-se com um programa atentatório à família, à \\ religião e àsSociedade. A Junta Regional de Santa Maria (LIGA..., 1933, p. \\ 1).
}

A Liga Eleitoral Católica surgiu no recorte de 1932-1934, com pretensões de inserir grupos de católicos na política brasileira. Definindo-se uma instituição suprapartidária, o objetivo era defender os princípios católicos, e a consolidação de tais preceitos dar-se-ia numa espécie de pacto estabelecido com os candidatos que se comprometessem por escrito a defender tais pressupostos.

Em Santa Maria, apesar dos conflitos existentes no âmbito da arquidiocese, consolidouse institucionalmente em novembro de 1932. O "Diário do Interior" registrou os bastidores da criação da instituição em 19 de novembro de 1932:

[...] como nos diversos pontos do estado, em Santa Maria, também, a Liga Eleitoral Católica Santa Maria, seção masculina. Na cidade, a Junta é dos Srs. Dr. Valentim Fernandes, presidente, Dr. João Appel Lens, $1^{\circ}$ secretário, Major Diogenes B. Pinheiro, Doutor Protásio Antunes de Oliveira, Consultor Jurídico. (A AÇÃO..., 1932, p. 2)

A notícia ainda informou sobre as organizações distritais, e empenho de Bispo Dom Antônio Reis, além de indicar as pretensões de reuniões, a fim de demarcar as qualificações políticas da instituição e as escolhas de propagandas eleitorais.

Apesar de fazer algumas ressalvas, por não ter realizado uma criteriosa análise acerca dos programas dos candidatos ao pleito, o bispo de Santa Maria, Dom Antônio Reis, apoiou os programas partidários "do Partido Republicano Liberal e do Partido Republicano Riograndense", devido à "atitude assumida pelos candidatos em relação aos problemas que na hora presente tanto preocupam os católicos brasileiros" (REIS, 1933, p. 4). 
Fica evidente a sua posição quando relaciona os interesses da nação com elementos do sagrado:

Católicos da Diocese de Santa Maria, vamos às URNAS, compactos e disciplinados! Cada um vote de acordo com suas convicções políticas, numa das três chapas apresentadas, tendo em vista acima de tudo o bem da pátria e da religião. Cumpramos acima de tudo nosso dever de brasileiros e católicos. (REIS, 1933, p. 4)

Além do mais, as posições de Fernando do Ó ecoaram sobre o mundo do operariado. Alguns indícios disso são deixados na publicação de 2 de maio de 1933, em que apresentava sua posição e justificava sua inserção política, no manifesto intitulado "Aos Meus amigos":

Não entrei na luta com ambições de posições mais altas nem volúpia de poder. Acedi, apenas, a instâncias de velhos companheiros de campanhas doutrinárias memoráveis. Sabia de antemão que meu humilde nome não escaparia à maledicência sectarista, mas ao ideal eu sacrifico e sacrificarei as vaidades próprias do homem. Se a gula política fosse a origem de minha candidatura, eu teria ficado no Partido Liberal que tantas vezes me acenou com cargos públicos. (Ó, 1933a, p. 1)

Podemos inferir a estratégia assumida pelo autor: uma tentativa discursiva de sacralização de si, ao enfatizar valores de humildade e sacrifício, já que inseria sua candidatura em tons de heroísmo. Nesse ponto, Fernando do Ó demonstrava sua interpretação peculiar de política. Sobre isso, enfatizava seu tempo de expectativas, suas novidades e a pretensão de fazer política de forma diferente, ligado a uma ética, e afirmava:

Promessas de lugar na Assembleia dos representantes ou na Câmara Federal de modo a envaidecer qualquer pessoa que não tivesse a vida cheia de trabalhos os mais penosos como eu tenho. A tudo renunciei e renuncio a prol das minhas convicções doutrinárias. (Ó, 1933a, p. 1) 
Por fim, a notícia ainda veiculou as posições do candidato sobre as indicações feitas aos trabalhadores acerca de sua candidatura. Novamente, Fernando do Ó assumia o discurso sob uma ética de pensar no outro:

Saído de classes mais humildes da sociedade - e com que orgulho eu o digo! - adquiri o feio vício de nunca arrastar os que sofrem o controle de seus chefes, às lutas glorificadas do meu ideal. Não quero que o voto do operariado acarrete a supressão de seu pão, nem o desconforto de sua família. Basta-lhes a vida obscura e cheia de lágrimas que levam pelas fábricas e oficinas, pelos campos e pelas cidades. (Ó, 1933a, p. 1)

A participação política de Fernando do Ó encaminha calorosos debates, estabelecendo redes de afetos, e, sobretudo, sobre a dimensão política do espiritismo, um tema tabu, principalmente nas suas representações institucionais. A discussão em torno disso evidencia o quanto esse discurso atrelava vários setores e organizações sociais. É, nessa perspectiva, que inferimos as solidariedades e as oposições configuradas no espaço social, demarcando a situação de tensão no campo religioso e suas ramificações sobre o político. $O$ laicismo arregimentou sociabilidades, formas de entendimento da política, e, em suma, indicava uma expectativa, respaldando a liberdade religiosa e o liberalismo, alvo de críticas no cenário intelectual dos anos 30 .

\section{Definições de conceitos: aliados, inimigos e Estado Laico}

Em 03 de maio de 1933, no dia da eleição para a Constituinte, na tentativa de responder às manifestações contrárias às propostas laicistas de Fernando do Ó, Daniel Cristovão ${ }^{12}$ manifestou-se, em artigo intitulado "A religião no Estado Leigo". Inicialmente, o autor disserta acerca do significado religioso no pensamento ocidental, ressaltando a importância do sagrado nos seguintes termos: "na posição de mentor que vai guiando com seus inteligentes e confortadores conselhos, os passos vacilantes dos homens 'humildes e pobres de espírito', na frase milenária de Jesus de Nazareth" (CRISTOVÃO, 1933a, p. 1).

\footnotetext{
12 Nascido em 29 de dezembro de 1901, português de nascimento, mas naturalizado brasileiro, na cidade de São Gabriel/RS. Militar, integrou a Força Expedicionária Brasileira durante a $2^{\text {a }}$ Guerra Mundial em 1942. Importante liderança espírita, doutrinador e orador, faleceu em 1953 na cidade de Campo Grande/RJ.
} 
Finalizado esses redimensionamentos das funções religiosas, a preocupação de Cristovão passa a ser a pluralidade e a diversidade religiosa e doutrinária no espaço social brasileiro. Primando pelas diferenças no campo das crenças, o $1^{\circ}$ Tenente destaca tanto a presença de doutrinas que, mesmo sem se definirem como religiões, apresentam postulados do amor e da tolerância, quanto daquelas que não admitem a existência divina, mas nem por isso podem deixar de ser respeitáveis. Assim, Cristovão condiciona a existência desse conjunto de sistemas doutrinários à liberdade. E ressalta que "a liberdade é para o pensamento o que o oxigênio é para a vida" (CRISTOVÃO, 1933a, p. 1).

O outro problema detectado pelo autor refere-se à oficialidade de um credo religioso no âmbito estatal. Assim, ele apresenta que a adoção de um sistema prejudica os vários outros sistemas, que serão restringidos ou anulados, prejudicando a coletividade (CRISTOVÃO, 1933a, p. 1).

Apesar de considerar importante a vinculação dos governantes a um sistema religioso, Daniel Cristovão reforça a importância do respeito e que todos os sistemas religiosos e de credo gozem da mesma parcela de liberdade:

Cada um que siga a crença que lhe aprouver, pois em nada prejudicará o andamento da locomotiva social que precisa da harmonia de todas as suas peças para marchar, e cuja harmonia se baseia na segurança e garantia das liberdades individuais na relação do modo de pensar em sentir. (CRISTOVÃO, 1933a, p. 1)

Enfim, evidenciam-se as relações políticas e os credos religiosos como importantes para a compreensão de sociedade. Nesse sentido, o autor ressalta, incisivamente, o desvio do sentido religioso ao envolver-se em questões da política. E argumenta que tal aliança representa violência e perda de sua legitimidade de persuasão frente seu fiéis. Nesse sentido, enfatiza que: "[...] como esse desagrada às massas, procura impor pela força. Quando uma religião embrenha-se por caminhos tão difíceis, está anunciando seu próximo fim” (CRISTOVÃO, 1933a, p. 1).

Concluindo, ele ratifica que a religião jamais deve envolver-se nos assuntos do Estado, argumentando que a conduta é primordial para que os homens procurem seu amparo a partir de uma escolha, e não uma imposição. Dessa leitura, o direito individual assumiu uma condição de exercício pleno de cidadania, questionando a validade e as fronteira do público e do privado no âmbito estatal. Fica clara a posição assumida acerca da relação religião e política, e esse binômio acaba sendo alvo de novas análises e posicionamentos. 
Diante disso, o problema da isenção política assume feições interessantes. Novamente, Daniel Cristovão manifestou-se no "Diário do Interior", a fim de esclarecer a sociedade santa-mariense. Em 26 de maio de 1933, publicou o texto intitulado "Os Candidatos do Espiritismo" em resposta ao artigo de Ivon Costa sobre as pretensões políticas do espiritismo e sua suposta transformação em partido político. Opondo-se a tal assertiva, Daniel Cristovão esclarece os leitores, acerca do Movimento Pró-Liberdade Religiosa, nos seguintes termos:

No terceiro e último Congresso Pró-Estado leigo, realisado em Montenegro, neste estado, dos dias 19, 20 e 21 de abril, um grupo de cem eleitores resolveu apresentar a candidatura à Constituinte, de vários cidadãos desassombradamente se hão pelo laicismo. Há entre eles positivistas, anticlericalistas, metodistas, protestantes, maçons e espíritas. Foi o bastante para que esse grupo de eleitores, das mais variadas crenças, amparados na lei, entendesse apresentar os mencionados candidatos, para que o Senhor Ivon Costa, por meio de conferências públicas e artigos pomposos, venha dizer que o espiritismo tem candidatos à Constituinte. (CRISTOVÃO, 1933b, p. 5)

Daniel Cristovão destaca, então, a onda de protestos que eclodiu a partir o da assinatura Decreto Federal $\mathrm{n}^{\circ}$ 19.941, de 30 de abril de 1931, que instituiu o ensino religioso facultativo nas escolas oficiais nos cursos primário, secundário e normal. Em sua opinião, tal arranjo significava:

Não houve instituição de caráter religioso ou doutrinário que não haja aderido a esse trabalho coletivo em prol do ensino e do estado leigos. Milhões e milhões de brasileiros, de norte ao sul das terras de Santa Cruz, hipotecaram solidariedade a essa causa comum. O "facultativo" todos sabem - em questão religiosa - é porta aberta para oficializado as práticas ao obrigatório. (CRISTOVÃO, 1933b, p. 5)

A seguir, as críticas direcionaram-se à figura de Ivon Costa. Nesse sentido, passou a ser alvo de discussão a prática de preleções espíritas em escolas públicas, condenadas porque fariam a pregação do espiritismo. Assim, uma compreensão de prática espírita evidencia -se nas falas da liderança, que escreve: 
Aqui mesmo em Santa Maria, temos uma escola pública primária, fundada e sustentada, pela Aliança Espírita, onde o professor já fez algumas conferências. E QUE POR SINAL QUIS VENDER A ENTRADA, QUIS FAZER NEGÓCIO NO ESPIRITISMO, como fazem os padres no Catolicismo. Só não levou a efeito sua ambição desmedida, porque foi impedido pelos espíritas sãos do São Espiritismo que se pratica nessa terra. Pois está convidado a visitar a aula pública da Aliança, frequentada por setenta crianças filhas de pais espíritas, católicos e protestantes, para ver se ali se prega alguma coisa acerca das almas do outro mundo. (CRISTOVÃO, 1933b, p. 5)

As possíveis relações entre comunismo e espiritismo são debeladas, ao afirmar que não pode ser confundido com partido político de espécie alguma já que o espiritismo ensina a regeneração lenta e progressiva do homem pelo amor e pela espontaneidade de sentimento, e o partido político impõe pelas armas uma igualdade impossível e asfixia o cidadão no ambiente intolerante do partido (CRISTOVÃO, 1933b, p. 5).

Cristovão evidencia as disputas internas vivenciadas no meio espírita, definindo e delimitando uma compreensão do que é e o que não é espiritismo. Assim, em "O Espiritismo Cindido", publicado em 18 de junho de 1933, Cristovão rebate as afirmações que constam em artigo publicado no jornal católico "Estrela da Manhã" acerca da fragmentação do espiritismo no Rio Grande do Sul e argumenta que as diferentes posições assumidas pelos espíritas decorrem de que eles são livres-pensadores, tendo o direito de divergir dos confrades e até dos pontos doutrinários, só afirmando aquilo que sua própria consciência aprova.

Nessa ideia, repudia os posicionamentos do jornal católico e afirma que, apesar das divergências entre o arcebispo de Porto Alegre e o bispo de Santa Maria, os jornais espíritas não se utilizaram desse argumento para divulgar que o catolicismo vivia momentos conturbados. E, devido a isso, resolve afirmar que o catolicismo estaria cindido por questões políticas (CRISTOVÃO, 1933c, p. 4).

As respostas escritas por Daniel Cristovão repercutem de forma decisiva. Uma possível discussão se estabelece entre o agente espírita e o padre Huberto Rodhen ${ }^{13}$. o cerne de tal discussão, sumariamente, refere-se ao suposto envolvimento do espiritismo na política, uma réplica ao padre Ricardo Liberali (CRISTOVAO, 1933c, p. 3) a respeito de uma publicação

\footnotetext{
${ }^{13}$ Nasceu em São Ludgero em 31 de dezembro de 1893. Sentindo o chamado ao sacerdócio, iniciou os estudos em nessa cidade, no seminário fundado na própria casa paroquial pelo Pe. Kloecker. Seguiu para o Rio Grande do Sul, onde estudou no seminário de padres jesuítas. Retornou a Santa Catarina emfins de 1919. Em1944, abandonou o celibato e, nos anos de 1950, elaborou a doutrina denominada de Espiritualismo Universalista.
} 
no jornal "Estrela da Manhã", em 22 de junho de 1933, e acusações de Daniel Cristovão ao clero como um todo.

Frente às acusações dos arranjos políticos orquestrados pela Liga Eleitoral Católica e afirmações de que o "Clero come, bebe, veste, lava-se, limpa-se, e prepara um regalado aposento no Céus às custas do povo" (CRISTOVÃO, 1933c, p. 3), e que os sacerdotes de Cristo ofereciam serviços profissionais em troca de remuneração, o padre Huber to Rohden escreve o texto "Pontinhos nós", em 8 de julho de 1933, no mesmo jornal, no qual pondera acerca dos posicionamentos de oposição ao dinheiro dos padres por parte de funcionários públicos. Sucintamente, o padre Rohden defende que estes também recebem dinheiro do povo. $\mathrm{E}$ repudia tais associações nos seguintes termos:

Embolsar mensalmente um pigue ordenado - em dinheiro do povo! e bancar depois o generoso e desinteressado amigo do povo e alardear a quatro ventos: "Eis que nós prestamos de graça todos os serviços sociais, religiosos e caritativos! - é procedimento insincero e desleal. (ROHDEN, 1933, p. 1)

A réplica de Cristovão Daniel rebate a compreensão do padre Rohden, ressaltando a profissionalização do sacerdócio como um emprego como qualquer outro. Dessa forma, inserindo tal postura na ordem moral do ensinamento de Cristo, critica o recebimento de dinheiro por orações e batizados, demarcando a diferença entre o sacerdócio e o funcionalismo público nos seguintes termos: "A diferença é que dos primeiros é ganho legal, em obediência às leis e regulamentos da nação, ao passo que o dos segundos é conseguido ilegalmente, de modo imoral" (CRISTOVÃO, 1933d, p. 4).

Os discursos aqui analisados convergem para os embates de perspectivas de mundo, pelos quais o laicismo arregimentou campos de luta política. É oportuno pensar tais vestígios a partir das novas experiências políticas com a ascensão de Vargas ao poder. A convocação de uma Assembleia Constituinte, em 1934, trouxe ao cenário público diferentes reivindicações, discussões e disputas. Nessa lógica, os diferentes grupos religiosos engajaram-se com suas pautas e tentativas de ganhar espaço, adeptos e poder na sociedade brasileira (COSTA, 2001).

A Igreja Católica, no combate ao ateísmo constitucional e a o laicismo, encontrará, na aproximação com o Governo Vargas, a legitimação de suas propostas, como o casamento religioso com efeitos civis e o ensino religioso facultativo em agremiações escolares e militares. Tal associação entre o poder político e o eclesiástico coincidia com um projeto 
comum: o controle político e religioso da população. Para os católicos, concretizava -se a possibilidade de voltar a gozar do privilégio de maior proximidade junto ao governo. Artur Cesar Isaia (1998) ressalta o realinhamento entre a Igreja Católica e o Estado brasileiro como a oportunidade de realização do nacionalismo católico, uma vez que tal aliança, de inspiração da reconquista tridentina, no plano social e educacional, possibilitava "uma margem de vantagens nunca vista s em relação aos oponentes" (ISAIA, 1998, p. 150).

A Coligação Nacional Pró-Estado Leigo, por sua vez, arregimentou forças opositoras a esse projeto católico. Tinha por propósito consolidar um Estado livre da intervenção religiosa. Logo, apesar da pluralidade organizacional, o engajamento e a presença de lideranças religiosas convergiam para a laicização do Estado. Segundo Costa (2001), a eleição para a Constituinte representava afastar o perigo nefasto e retrógrado da Igreja. A luta pela laicidade e independência religiosa, portanto, representava a consolidação de uma experiência democrática inaugurada na Constituição de 1891. Dessa forma, os agentes asseveravam para a liberdade de religiosa e a participação dos eventos religiosos sem qualquer tipo de constrangimento.

Evaristo Menna Barreto Jaime, secretário da Liga Rio Grande do Sul, evidencia os anseios da agremiação ao afirmar que: "Nada pleiteamos, nada pedimos, senão que seja mantida intangível uma das mais gloriosas conquistas da civilização moderna - a liberdade ampla de consciência" (JAIME, 1932). Assim, no presente contexto, o engajamento de tantas lideranças religiosas pelo estado laico durante o Governo de Vargas esteve relacionado à manutenção do previsto no Art. 72 da Constituição Federal. Traziam a crença na validade jurídica de tal experiência, com toda a fé no laicismo e nos ideais republicanos.

Percebemos, a partir desses aspectos, elementos de uma cultura política. Assim, o laicismo corresponderia ao elemento comum entre republicanos, maçons, espíritas e protestantes. Autores como Eliane Moura Silva (2012), Marcos José Diniz Silva (2009) e Marcelo Gil (2008) assinalam a complexidade e o ecletismo entre os fins do século XIX e a primeira metade do século $\mathrm{XX}$ que compunham tais configurações sociais. Em tese intitulada "Moderno-espiritualismo e espaço público republicano: maçons, espíritas e teosofistas no Ceará" (SILVA, 2009), Marcos José Diniz Silva caracteriza como pródigas as relações entre maçonaria, espiritismo, protestantismo e teosofia, inserindo-os numa rede de pensamento, de trocas, solidariedades e tensões.

Marcos Diniz Silva (2009), ainda, de forma bastante elucidativa, situa uma atuação efervescente desses grupos, e assinala o ano de 1937 como divisor de água, já que inúmeros centros espíritas e lojas maçônicas sofreram intervenção, conforme o previsto na letra C do Art. 168 da Constituição outorgada em 1937, a respeito da suspensão da liberdade de reunião por motivo de segurança. Suas lutas e atitudes sociopolíticas correspondem a uma intrincada rede de afetos e aproximações. A reforma moral estava associada a interesses disciplinares-civilizatórios da burguesia e classes dominantes locais. Defensora da 
racionalidade, do cientificismo e do republicanismo, tais agentes eram portadores de um projeto social em oposição ao que definem de tradicionalismo da Igreja Católica .

Diante de tais questões, antes de pensar o significado de uma cultura laicista nos anos de 1930, infere-se como esses grupos teciam suas lógicas, inventavam suas opções políticas, construíam, pensavam e liam o mundo, bem como de que modo davam sentido aos interesses em jogo (SILVA, 2012, p. 87). Evidentemente que este artigo não esgota tal assunto, inúmeros pontos, como as táticas discursivas de conciliação religiosa e pa triotismo e suas formas de divulgação, a relação hierárquica estabelecida entre as diferentes ligas carecem de análises sistemáticas, assim como as relações maçonaria, espiritismo e protestantismo, suas redes de tensões e solidariedades e a própria conquista.

Neste artigo, por outro lado, evidenciamos o discurso que emana poder, cujo exercício impõe a presença do político no religioso, sendo assim, a liberdade religiosa assumia contornos de significação democrática. Fato que a conquista de uma cadeira junto à Assembleia Nacional Constituinte por parte da liderança.

\section{Considerações finais}

Os vários argumentos defendidos a respeito das posições religiosas e políticas adotadas indicam o choque de visões de mundo. As estratégias elaboradas na estrutura social dão novos significados para a presença da religião no espaço social. O mundo liberal e laico que Fernando do Ó representava utilizou-se de diversas formas para se fazer presente no espaço majoritariamente católico. Defendendo a liberdade e o direito de expressão, respaldou-se no laicismo como bandeira da legalidade, afirmando a possibilidade de convivência entre as diferentes vertentes religiosas.

Assim, percebemos, conforme Bourdieu (1996), que os agentes atuam ativamente no mundo e elaboram suas visões de mundo. A Constituição de 1891 definiu fundamentos das relações entre Estado e religião, tendo o conceito de laicidade assumido dimensões próprias conforme os agentes envolvidos. Todos esses elementos estariam relacionados ao conjunto de disputas em torno da interpretação e uso da noção de laicidade, ora usada como expectativa, ora como ameaça para os grupos envolvidos na disputa por espaço para oferta de seus argumentos, como buscamos demonstrar no contexto da década de 1930. Inclusive, o sentido de democracia vinculada à liberdade religiosa, e tal garantia, frequentemente retomada como experiência inauguradora no campo da liberdade religiosa e de uma 
perspectiva de laicidade, logo, o engajamento de Fernando do Ó e demais lideranças religiosas fundia-se a tal dimensão de defesa da legalidade jurídica e constitucional.

É nesse sentido que a atuação de Guaraci Silveira, pastor metodista, eleito pela legenda do Partido Socialista, trouxe para o interior da Assembleia Nacional Constituinte a problemática das minorias religiosas. Propondo, inclusive, a substituição do Ensino Religioso pela Educação Moral e Cívica, e contando com o apoio de liberais, positivistas e maçons para ratificar a garantia de liberdades individuais das diferentes vertentes religiosas (ALMEIDA, 2002). Os episódios aqui brevemente expostos evidenciavam os campos de lutas em torno da nacionalidade, e em meio à oposição e aos gritos de grupos ligados à Liga Eleitoral Católica - LEC de que "sem religião não há moral", aguçam a reflexão em torno das experiências políticas e sua relação com a delimitação do religioso no espaço público, ou seja, as questões de laicidade como parte integrante da cultura política brasileira.

Enfim, diante do até então discutido, inferimos a atuação desses homens e mulheres enquanto problematizadores de conceitos como Estado, republicanismo, laicismo, lei, cidadania e as fronteiras entre o público e o privado. Assim, tais vestígios confirmam o lugar social de onde falavam e seu combate ao projeto católico de reconquista de influência na sociedade brasileira após 1891 . Seus engajamentos servem-nos de incentivo para a retomada da discussão do religioso e como o mesmo ponto era tido como central para experiência democrática durante a primeira metade do século XX.

\section{Referências}

A AÇÃO catholica em Santa Maria. Diário do Interior, Santa Maria, n. 260, 19 nov 1932.

ABREU, Luciano. Um olhar regional sobre o estado novo. Porto Alegre: EDIPUCRS, 2007.

ALMEIDA, Vasni. Ensino religioso ou educação moral e cívica. Revista de Educação do COGEIME, Piracicaba, v. 21, p. 25-42, 2002.

AZEVEDO, Antonio Carlos do Amaral. Dicionário de nomes, termos e conceitos históricos. Rio de Janeiro: Nova Fronteira, 1999.

BIASOLI, Vitor. O catolicismo ultramontano e a conquista de Santa Maria (1870/1920). Santa Maria: Editora da UFSM, 2010. 
BORIN, Marta Rosa. Por um Brasil católico: tensão e conflito no campo religioso da República. 2010. Tese (Doutorado em História) - Programa de Pós-Graduação em Estudos Históricos Latino-Americanos, UNISINOS, São Leopoldo, 2010.

BOURDIEU, Pierre. A economia das trocas simbólicas. São Paulo: Perspectiva, 1996.

CARDOSO, Edmundo. História da Comarca de Santa Maria. Santa Maria: Imprensa da UFSM, 1978.

CEPEDA, Vera Alves. Contexto político e crítica à democracia liberal: a proposta de representação classista na Constituinte de 1934. In: MOTA, Carlos Guilherme (Org.). Os juristas e a formação do Estado-Nação: pós 1930. São Paulo: Ática, 2009.

COMITE Pró-Liberdade Da Consciência. Diário do Interior, Santa Maria, n. 12, 15 jan. 1931.

CONY, Diogenes et al. Ao eleitorado Rio-Grandense. Diário do Interior, Santa Maria, n. 83, 16 abr. 1933.

CORRÊA, Fernando. Fernando do Ó: a caminho da luz. Santa Maria: Palocci, 2004.

COSTA, Flamarion. Demônios e anjos: o embate entre espíritas e católicos na República Brasileira até a década de 60 do século XX. 2010. Tese (Doutorado em História) Universidade Federal do Paraná, Curitiba, 2010.

COUTROT, Aline. Religião e política. In: RÉMOND, René. Por uma história política (Org.). Tradução de Dora Rocha. Rio de Janeiro: Editora UFRJ, 1996. p. 331-364.

CRISTOVÃO, D. As religiões no Estado Leigo. Diário do Interior, Santa Maria, n. 95, 3 maio 1933a.

CRISTOVÃO, D. Os candidatos do espiritismo. Diário do Interior, Santa Maria, n. 115, 26 maio 1933b.

CRISTOVÃO, D. Pontinhos nos. Diário do Interior, Santa Maria, n. 152, 11 jul. 1933d.

CRISTOVÃO, D. Réplica ao Padre Ricardo Liberali. Diário do Interior, Santa Maria, n. 148, 6 jul. 1933c.

ELMIR, Claudio Pereira. As armadilhas do jornal: algumas considerações metodológicas de seu uso para a pesquisa histórica. Cadernos do PPG de História UFRGS, Porto Alegre, n. 13, p. 1929, dez. 1995. 
GIL, Marcelo Freitas. O movimento espírita pelotense e suas raízes sócio-históricas e culturais. 2008. 184 f. Dissertação (Mestrado em Ciências Sociais) - Universidade Federal de Pelotas, Pelotas, 2008.

GOMES, Angela Maria de Castro. Autoritarismo e corporativismo no Brasil: o legado de Vargas. Revista USP, São Paulo, n. 65, p. 105-119, $2005 a$.

GOMES, Angela Maria de Castro. História, historiografia e cultura política no Brasil: algumas reflexões. In: SOIHET, Rachel; BICANHO, Maria Fernanda Baptista; GOUVÊA, Maria de Fátima Silva (Org.). Cultura política: ensaios de história cultural, história política e ensino de história. Rio de Janeiro: Mauad, 2005b. p. 21-44.

GOMES, Angela Maria de Castro. Confronto e compromisso no processo de constitucionalização. In: FAUSTO, Boris (Org.). História geral da civilização brasileira. Rio de Janeiro: Bertrand Brasil, 1990. p. 7-119.

ISAIA, Artur Cesar. Catolicismo e autoritarismo no Rio Grande do Sul. Porto Alegre: EDIPUCRS, 1998.

JAIME, E. Pela liberdade de culto: apelo da liga pró - estado leigo. Correio do Povo, Porto Alegrem 10 mar. 1932.

KARSBURG, Alexandre de Oliveira. Sobre as ruínas da Velha Matriz: religião e política em tempos de ferrovia - Santa Maria - Rio Grande do Sul 1880 - 1890. Santa Maria: UFSM, 2007.

LE GOFF, Jacques. História e memória. Campinas: Unicamp, 1990.

LIGA eleitoral catholica. Aviso aos Eleitores. Diário do Interior, Santa Maria, n. 87, 21 abr. 1933.

LUCA, Tânia Regina. História dos, nos e por meio dos periódicos. In: PINSKY, Carla Bassanezi. Fontes históricas. São Paulo: Editora Contexto, 2005. p. 111-153.

MICELI, Sergio. Intelectuais à brasileira. São Paulo: Companhia das Letras, 2001.

MONTEIRO, L. Os católicos gaúchos e a construção da ordem política: a liga eleitoral católica. Revista Brasileira de História das Religiões, Maringá, v. 2, p. 118-148, 2008. Disponível em: <http://periodicos.uem.br/ojs/index.php/RbhrAnpuh/article/ view/26645>. Acesso em: 21 nov. 2016.

MORAES, Maria Célia Marcondes de. Educação e política nos anos 30: a presença de Francisco Campos. Revista Brasileira de Estudos Pedagógicos, Brasília, v. 73, n. 174, p. 291-321, maio/ago. 1992.

Ó, Fernando. Aos meus amigos. Diário do Interior, Santa Maria, n. 95, 2 maio 1933a. 
Ó, Fernando. Manifesto dô Doutor Fernando do Ó às forças eleitoraes do Rio Grande do Sul. Diário do Interior, Santa Maria, n. 83, 16 abr. 1933b.

PRÓ-LIBERDADE religiosa. Diário do Interior, Santa Maria, n. 240,12 mar 1930.

REIS, A. Manifesto da liga eleitoral catholica da diocese de Santa Maria. Diário do Interior, Santa Maria, n. 89, 25 abr. 1933.

ROHDEN, H. Pontinhos nos. Diário do Interior, Santa Maria, n. 150, 8 jul. 1933.

SILVA, Eliane Moura. Entre religião e política: maçons, espíritas, anarquistas e socialistas no Brasil por meio dos jornais A Lanterna e o Livre Pensador (1900-1909). In: ISAIA, Artur Cedas; MANOEL, Ivan Aparecido (Org.). Espiritismo e religiões afro-brasileiras: história e ciências sociais. São Paulo: Ed Unesp, 2012. p. 87-101.

SILVA, Marcos José Diniz. Moderno-espirutualismo e espaço público republicano: maçons, espíritas e teosofistas no Ceará. 2009. 343 f. Tese (Doutorado em Sociologia) - Universidade Federal do Ceará, Fortaleza, 2009.

VÉSCIO, L. A Ultramontana Santa Maria - RS: sede da quarta colônia de imigração italiana. In: SANTA MARIA. Prefeitura Municipal. Nova história de Santa Maria: contribuições recentes. Santa Maria: Câmara de Vereadores de Santa Maria, 2010. p. 197-224.

ZICMAN, Renée Barata. História através da imprensa: algumas considerações e metodológicas. Revista do Programa de Estudos Pós-Graduados em História/PUCSP, São Paulo, n. 4, 1985. Disponível em: <https://revistas.pucsp.br/index.php/ revph/article/view/12410/8995>. Acesso em: 21 mar. 2017.

Recebido em 22/07/2016

Aprovado em 30/01/2017 